\title{
Soil phosphorus availability after slash-and-burn fires of different intensities in rubber agroforests in Sumatra, Indonesia
}

\author{
Quirine M. Ketterings ${ }^{\mathrm{a}, *}$, Meine van Noordwijk ${ }^{\mathrm{b}}$, Jerry M. Bigham ${ }^{\mathrm{c}}$ \\ a Environmental Sciences Graduate Program, The Ohio State University, Columbus, OH, USA \\ ${ }^{\mathrm{b}}$ International Center for Research in Agroforestry, Southeast Asian Regional Program, P.O. Box 161, Bogor 16001, Indonesia \\ c School of Natural Resources, The Ohio State University, 210 Kottman Hall, 2021 Coffey Road, Columbus, OH 43210, USA
}

Received 12 May 2000; received in revised form 25 July 2001; accepted 2 August 2001

\begin{abstract}
Land clearing fires in Sumatra, Indonesia, caused enormous environmental problems for southeast Asia in 1997, but rubber farmers as well as large rubber and oil palm plantation owners continued to slash-and-burn due to the lack of an alternative that is equally quick, cheap, and capable of improving soil fertility. A partial alternative may be found in the reduction of the fuel load before the burn by harvesting and selling a larger fraction of the wood and, thus, changing the intensity of the fire and reducing particulate and greenhouse gas emission. An adequate phosphorus (P) supply is critical to crop production in Sumatra. Thus, it is important to understand the effects of such a reduction in fire intensity on crop P availability. Field and laboratory experiments were conducted to: (1) determine P sorption capacities and affinity constants for a forest soil exposed to different fire intensities in a controlled oven experiment (heat effects only); (2) compare the sorption characteristics of oven-burned soil with field-burned soil (heat and ash addition effects); and (3) determine the effects of fire-induced changes in soil properties on indices of $\mathrm{P}$ availability. Sorption experiments using oven-heated forest soil showed an increase in both the maximum amount of $\mathrm{P}$ it can hold (P sorption capacity, $X_{\mathrm{m}}$ ) and the strength with which this $\mathrm{P}$ is retained to soil particles (affinity constant, $K$ ) with heating to $450^{\circ} \mathrm{C}$. Field burning resulted in similar increases in $X_{\mathrm{m}}$ but reduced the affinity constants in the surface $15 \mathrm{~cm}$ soil. The increase in $X_{\mathrm{m}}$ was related to a fire-induced increase in specific surface area of the mineral fraction. The addition of ash in field burns appeared to be responsible for the observed decrease in $K$. The increase in $X_{\mathrm{m}}$ is expected to enlarge the need for $\mathrm{P}$ fertilizers as soon as solution $\mathrm{P}$ declines to pre-burn levels. These mineralogy-based changes in $\mathrm{P}$ sorption characteristics of surface soil are expected to be long-term and could reduce the time period for sustained annual crop production, establishment of new rubber plantations from seeds, as well as affect soil loss and sustained rubber production. In managing the intensity of slash-and-burn fires, the farmer, thus, has to balance between short-term gains in $\mathrm{P}$ availability and long-term costs in increased P sorption.
\end{abstract}

() 2002 Elsevier Science B.V. All rights reserved.

Keywords: Oxisols; Phosphorus; Slash-and-burn; Indonesia; Rubber agroforestry

* Corresponding author. Present address: Department of Crop and Soil Sciences, Cornell University, 817 Bradfield Hall, Ithaca, NY 14853, USA. Tel.: +1-607-255-3061; fax: +1-607-255-7656. E-mail address: qmk2@cornell.edu (Q.M. Ketterings).

\section{Introduction}

Large plantation holders as well as small-scale rubber producers in Sumatra, Indonesia, use fire as a tool for land clearing. Fires related to land clearing in 1997 led to enormous air pollution problems for Indonesia 
as well as for the entire southeast Asia region (Simons, 1998). Alternatives to the current use of fire are needed to prevent the occurrence of similar disasters in the future. A partial alternative may be found in the reduction of the fuel load before the burn by harvesting and selling a larger fraction of the wood.

In rubber (Hevea brasiliensis) agroforestry systems on the acidic Oxisols and Ultisols of Sumatra, phosphorus $(\mathrm{P})$ is the major growth-limiting nutrient (van Noordwijk et al., 1995, 1998). Under forest cover, losses of $\mathrm{P}$ due to leaching, erosion and/or harvest removal are limited and $\mathrm{P}$ accumulates in the aboveground biomass. Organic material is recycled within the ecosystem in the litter layer, partly bypassing the mineral soil where $\mathrm{P}$ sorption and fixation capacities are high because of low activity clays and low $\mathrm{pH}$ (Tiessen et al., 1994). Phosphorus mineralization replenishes the labile and soil solution inorganic pools, although a pool of occluded organic P may gradually build up.

This situation changes when forests are converted to agricultural fields, especially when fire is used as the tool for land clearing. The above ground biomass of secondary forests (age 15 to $>60$ years) in Jambi Province, Sumatra, ranged from 49 to $225 \mathrm{mg}$ dry weight ha ${ }^{-1}$ (unpublished results). During the burn of such forests, part of the P previously held in the vegetation will be lost in the form of particulates that are carried into the atmosphere and deposited beyond the burning field, contributing to the fertility of neighboring sites. The rest is deposited on top of the soil as a component of ash or charred and partly combusted organic material, which may release $\mathrm{P}$ through decomposition over time. The fire may also release $\mathrm{P}$ from other soil organic pools through the combustion and/or enhance mineralization of soil organic matter. Phosphorus that enters the soluble $\mathrm{P}$ pool may be taken up by plants, chemisorbed to the surfaces of $\mathrm{Fe}$ and $\mathrm{Al}$ oxides, or precipitated as relatively insoluble $\mathrm{Al}$ and Fe phosphates.

Numerous studies have shown a fire-induced increase in various indices of plant available $\mathrm{P}$ directly following the burn (e.g. Nye and Greenland, 1960; Slaats et al., 1998; van Reuler, 1996, Andriesse and Koopmans, 1984, Juo and Manu, 1996). Most studies have related this apparent increase in available $\mathrm{P}$ to ash addition, per se. However, high intensity fires have the potential to cause changes in soil properties through heat exposure. Sreenivasan and Aurangabadkar (1940) and Ulery and Graham (1993) reported a coarsening in soil texture after intense burns. Mineralogical analyses of clay fractions from field-burned soil in Indonesia (reported in Ketterings et al., 2000) showed that kaolinite quantities were drastically reduced in combusted samples, that gibbsite was partially decomposed at lower temperatures $\left(>300^{\circ} \mathrm{C}\right)$ and was not detectable in the combusted topsoil while goethite was converted to ultra-fine maghemite as a result of heat exposure. Such high temperatures are not uncommon in mature, secondary forest burns in Sumatra. High surface temperatures were reported in other studies as well (e.g. Sertsu and Sanchez, 1978).

These changes in soil mineralogy may be related to changes in $\mathrm{P}$ dynamics observed by Romanya et al. (1994), Kwari and Batey (1991) and Serrasolsas and Khanna (1995). However, it is not well understood how heat-induced changes in texture and mineralogical composition affect the total surface area of mineral soil particles (as an indicator of $\mathrm{P}$ sorption capacity), the maximum amount of $\mathrm{P}$ that can be held by the soil (P sorption capacity, $X_{\mathrm{m}}$ ) and the strength with which this $\mathrm{P}$ is retained to the soil particles (affinity constant, $K$ ). A combined increase in $\mathrm{P}$ affinity and sorption capacity is expressed as greater $\mathrm{P}$ fixation. In addition, it is not known how important these changes are as compared to the (temporary) effects of ash addition, what the impact of fire on dissolved organic $\mathrm{C}$ (DOC) content in soil solution is on $\mathrm{P}$ cycling following a burn and how these changes impact long-term sustainability of annual and tree-based cropping systems. Only when these changes and interactions are fully understood can alternatives be developed that address the disadvantages as well as the advantages of the presently used slash-and-burn system and alternatives such as pre-burn wood removal.

Field and laboratory experiments were conducted to: (1) determine $\mathrm{P}$ sorption capacities and affinity constants for a forest soil exposed to different fire intensities in a controlled oven experiment (heat effects only); (2) compare the sorption characteristics of oven-burned soil with field-burned soil (heat and ash addition effects); and (3) determine the relationships between fire-induced changes in mineral particle surface area (indicator of P sorption capacity), dissolved soil $\mathrm{C}$ (competitor of $\mathrm{P}$ for sorption sites) and indices of $\mathrm{P}$ plant availability. 


\section{Materials and methods}

\subsection{Field soil sampling}

Bulk (4-5 kg) soil samples were collected from two layers, hereafter referred to as surface soil $(0-5 \mathrm{~cm})$ and sub-surface soil $(5-15 \mathrm{~cm})$, from a recently burned, 20-years-old secondary forest in the Sepunggur area, Jambi Province, Sumatra, Indonesia $\left(102^{\circ} 14^{\prime} \mathrm{E}, 1^{\circ} 29^{\prime} \mathrm{S}\right)$. Although burning of tree-root systems could lead to combusted soil to a depth of $50 \mathrm{~cm}$ (Ketterings et al., 2000), heat-sensitive crayons used in secondary burn trials in the same region indicated limited heat transfer beyond $15 \mathrm{~cm}$ depth where maximum surface temperatures were $600^{\circ} \mathrm{C}$ or lower (unpublished results). Thus, sampling for this study was limited to the surface $15 \mathrm{~cm}$. The soils in this region of Sumatra are classified as Hapludox and Kandiudox according to US Soil Taxonomy (Soil Survey Staff, 1999) and as Orthic Ferralsols according to the FAO classification. In Sumatra, small-scale rubber $(H$. brasiliensis) and large-scale timber and oil palm (Elaeis guineensis) plantations are the dominant land use. See van Noordwijk et al. $(1995,1998)$ for a detailed description of the climate, vegetation, soils and land use in the region and Ketterings et al. (1999) for a description of slash-and-burn practices in the area. Individual samples were collected within a $30 \mathrm{~m} \times 40 \mathrm{~m}$ plot at locations where the surface temperature of the broadcast burn had reached 100, 300 and $600{ }^{\circ} \mathrm{C}$ as measured with heat-sensitive crayons (Cole Parmer, Venon Hills, IL). For each temperature exposure level, samples from five locations were composited. To study the effects of heat exposure on originally unburned soil (oven experiments), additional soil samples were taken in the surround- ing forest (hereafter referred to as forest soil). See Table 1 for general soil fertility and mineralogical characteristics of the forest soil. A sub-sample of red, combusted topsoil was obtained from locations where surface temperatures exceeded $600^{\circ} \mathrm{C}$. All samples were taken 2 weeks after the burn, air dried, and sieved to pass $2 \mathrm{~mm}$ prior to further analyses.

\subsection{Oven experiment}

Sub-samples of $30 \mathrm{~g}$ unburned, air-dried, forest soil from both sample depths $(0-5$ and $5-15 \mathrm{~cm})$ were placed in ceramic crucibles and heated in a muffle furnace to temperatures of $100,300,450$ and $600^{\circ} \mathrm{C}$ for a duration of $30 \mathrm{~min}$ (batch study, $n=2$ ). The samples were allowed to cool to room temperature in a dessicator prior to weight loss determinations and further physical and chemical analyses.

\subsection{Phosphorus sorption}

Phosphorus sorption experiments were conducted with both oven-heated and field-burned surface soils. Sub-samples of $1.5 \mathrm{~g}(n=2)$ were shaken with $20 \mathrm{ml}$ of $0.01 \mathrm{M} \mathrm{NaCl}$ containing $0,32,74,163,237$ or $289 \mathrm{mg} \mathrm{Pl}^{-1}$ (added as $\mathrm{KH}_{2} \mathrm{PO}_{4}$ ) on a reciprocal shaker at room temperature for $66 \mathrm{~h}$. To separate the liquid from the solid fraction, samples were centrifuged at $3000 \mathrm{rpm}$ for $30 \mathrm{~min}$ immediately after the shaking period. The amount of sorbed $\mathrm{P}$ per gram of soil was calculated as the difference between the initial and the final $\mathrm{P}$ concentrations in the $0.01 \mathrm{M} \mathrm{NaCl}$ extract solution. The maximum sorption capacity $\left(X_{\mathrm{m}}\right.$ in $\mathrm{mg} \mathrm{P} \mathrm{kg}{ }^{-1}$ soil) and $K\left(\right.$ in $\left.1 \mathrm{mg}^{-1}\right)$ were estimated from

Table 1

Physical and mineralogical properties of an Oxisol under rubber agroforestry management in Jambi Province, Sumatra, Indonesia ${ }^{a}$

\begin{tabular}{|c|c|c|c|c|c|c|c|c|}
\hline $\begin{array}{l}\text { Depth } \\
(\mathrm{cm})\end{array}$ & Mineralogy & Color & $\mathrm{pH}$ & $\begin{array}{l}\text { Sand } \\
\left(\mathrm{g} \mathrm{kg}^{-1}\right)\end{array}$ & $\begin{array}{l}\text { Silt } \\
\left(\mathrm{g} \mathrm{kg}^{-1}\right)\end{array}$ & $\begin{array}{l}\text { Clay } \\
\left(\mathrm{g} \mathrm{kg}^{-1}\right)\end{array}$ & $\begin{array}{l}\mathrm{OC}^{\mathrm{b}} \\
\left(\mathrm{g} \mathrm{kg}^{-1}\right)\end{array}$ & $\begin{array}{l}\text { CBD-Fe } \\
\left(\mathrm{g} \mathrm{kg}^{-1}\right)\end{array}$ \\
\hline $0-5$ & $\begin{array}{l}\text { Kaolinite }(73 \%) \text {, gibbsite ( } 4 \%) \text {, } \\
\text { goethite, and quartz }\end{array}$ & $2.6 \mathrm{Y} \quad 6.7 / 1.4$ & $4.5(0.1)$ & $13(3)$ & 398 (4) & $590(6)$ & $67(1.0)$ & $12(0.4)$ \\
\hline $5-15$ & $\begin{array}{l}\text { Kaolinite (66\%), gibbsite (5\%), } \\
\text { goethite, and quartz }\end{array}$ & 4.9Y 7.4/1.0 & $4.6(0.2)$ & $9(1)$ & $428(35)$ & $564(6)$ & $20(0.4)$ & $24(0.1)$ \\
\hline
\end{tabular}

\footnotetext{
${ }^{a}$ The soil from this site was used for oven experiments described in this study; values in parenthesis are standard deviations.

b OC: organic C.

${ }^{\mathrm{c}} \mathrm{CBD}-\mathrm{Fe}$ : citrate-bicarbonate-dithionite extractable Fe.
} 
the linear form of the modified Langmuir isotherm (Kuo, 1988):

$$
\begin{aligned}
& X=X_{\mathrm{m}}-K^{-1 / 2} \times X_{\mathrm{m}}^{1 / 2} \times\left(\frac{X}{C}\right)^{1 / 2} \text { or } \\
& C=\frac{X \times X_{\mathrm{m}}}{K \times\left(X_{\mathrm{m}}-X\right)^{2}} \text { for } X<X_{\mathrm{m}}
\end{aligned}
$$

where $X$ is the amount of $\mathrm{P}$ sorbed per unit mass of soil ( $\mathrm{mg} \mathrm{P} \mathrm{kg}^{-1}$ soil) and $C$ is the $\mathrm{P}$ concentration of the equilibrium solution $\left(\mathrm{mg} \mathrm{P}^{-1}\right.$ extraction solution). The fitted modified Langmuir equations were used to calculate distribution coefficients $\left(K_{\mathrm{d}}\right)$ of oven-heated soil samples at a range of soil solution concentrations. The distribution coefficient, estimated as $X / C$ after conversion to common units, can be interpreted as an estimate of $\mathrm{P}$ availability in the soil (van Rees et al., 1990).

To investigate the effect of a fire-induced conversion of goethite to maghemite (Ketterings et al., 2000), the maximum $P$ sorption capacity of synthetic goethite and maghemite (according to Schwertmann and Cornell, 1991) were determined by shaking $0.15 \mathrm{~g}$ samples for $66 \mathrm{~h}$ with 16,24 , or $29 \mathrm{mg} \mathrm{Pl}^{-1}$ in $15 \mathrm{ml}$ aliquots. After shaking, these samples were processed and analyzed like the soil samples.

\subsection{Physical and chemical analyses of soil}

Particle size analyses were performed on the field-burned samples using standard sieve and pipet methods (Kilmer and Alexander, 1949) following removal of organic matter with $30 \% \mathrm{H}_{2} \mathrm{O}_{2}$. Due to time and budget constraints, particle size of oven-heated samples was not determined.

Specific surface areas of the clay, silt and sand fractions from each of the field-burned samples were determined by adsorption of $\mathrm{N}_{2}$ using the single-point, continuous flow method (ASTM, 1990). A Micromeritics Flowsorb II 300 instrument (Micromeritics Corp., Norcross, GA) was calibrated at the beginning of each operating period by injecting a known volume of analytical grade $\mathrm{N}_{2}$. Two standard reference materials were also analyzed for calibration purposes. The quantities of both standards and samples were adjusted to yield surface areas in the range of $0.5-25 \mathrm{~m}^{2}$ as per instrument manufacturer's specifications.
Field-burned samples were analyzed for total organic $\mathrm{C}$ by the Walkley-Black procedure (Walkley, 1947). Extracts from the $P$ sorption experiment (static heating) were analyzed for dissolved total and inorganic C using a Dohrmann DC-190 high temperature $\mathrm{C}$ analyzer equipped with a non-dispersive infrared detector (Rosemount Analytical Inc.). DOC was calculated as the difference between total and inorganic C. All P extracts and equilibrium solutions from the oven experiment were colorimetrically analyzed for total $\mathrm{P}$ using the ammonium molybdate method (QuickChem method 10-115-01-1-1-B) and an AE QuikChem Lachat analyzer (Lachat Instruments, WI).

The forest soil was characterized for iron oxides and color. The concentration of crystalline iron oxides (except magnetite) was determined in a citrate-bicarbonate-dithionite (CBD) extract (Mehra and Jackson, 1960). Final extracts were analyzed for $\mathrm{Fe}\left(\mathrm{Fe}_{\mathrm{d}}\right)$ by atomic absorption spectrophotometry. A CR-300 colorimeter (Minolta Corp., Ramsey, NJ) was used to determine Munsell color.

\subsection{Statistical analyses}

The results of the oven experiments were analyzed as a two-way ANOVA in two replicates with temperature of exposure and amount of added $\mathrm{P}$ as the factors using Genstat 5 for Windows 95 (Genstat, 1993). The same software package was used for regression analyses (Langmuir equation).

\section{Results and discussion}

\subsection{Maximum soil P sorption capacity}

The $X_{\mathrm{m}}$ of the $0-5 \mathrm{~cm}$ layer of unburned forest soil was $\sim 2200 \mathrm{mg} \mathrm{Pkg}^{-1}$ soil, whereas $X_{\mathrm{m}}$ for the $5-15 \mathrm{~cm}$ layer amounted to $1900 \mathrm{mg} \mathrm{P} \mathrm{kg}^{-1}$ soil (Table 2). These values of $X_{\mathrm{m}}$ are high but comparable to results obtained by Syers et al. (1973) who estimated an $X_{\mathrm{m}}$ of $\sim 1800 \mathrm{mg} \mathrm{P} \mathrm{kg}^{-1}$ soil for a clay soil with similar mineralogy.

Oven burning the forest soil to $450{ }^{\circ} \mathrm{C}$ increased the maximum sorption capacity of the $0-5 \mathrm{~cm}$ layer to $\sim 2800 \mathrm{mg} \mathrm{P} \mathrm{kg}^{-1}$ soil (Table 2). Exposure to higher temperatures resulted in a subsequent decrease in $X_{\mathrm{m}}$. The $X_{\mathrm{m}}$ of the $5-15 \mathrm{~cm}$ layer increased 
Table 2

Sorption maxima $\left(X_{\mathrm{m}}\right)$ for oven-heated ${ }^{\mathrm{a}}$ surface $(0-5 \mathrm{~cm})$ and sub-surface soil $(5-15 \mathrm{~cm})$ and field-heated surface soil $(0-5 \mathrm{~cm})$ from Jambi Province, Sumatra, Indonesia

\begin{tabular}{lllr}
\hline $\begin{array}{l}\text { Temperature of } \\
\text { exposure }\left({ }^{\circ} \mathrm{C}\right)\end{array}$ & Field-heated soil $\left(\mathrm{mg} \mathrm{P} \mathrm{kg}^{-1}\right)$ & Oven-heated soil $\left(\mathrm{mg} \mathrm{P} \mathrm{kg}^{-1}\right)$ \\
\cline { 2 - 3 } & $0-5 \mathrm{~cm}$ & $0-5 \mathrm{~cm}$ & $5-15 \mathrm{~cm}$ \\
\hline Unburned forest & N.D. ${ }^{\mathrm{b}}$ & $2187\left(0.95^{*}\right)^{\mathrm{c}}$ & $1900\left(0.88^{*}\right)$ \\
100 & $2484\left(0.97^{*}\right)$ & $2218\left(0.94^{*}\right)$ & $1803\left(0.87^{*}\right)$ \\
300 & $2700\left(0.99^{*}\right)$ & $2703\left(0.92^{*}\right)$ & $2261\left(0.89^{*}\right)$ \\
450 & N.D. & $2809\left(0.96^{\text {ns }}\right)$ & $2626\left(0.91^{*}\right)$ \\
600 & $3226\left(0.98^{*}\right)$ & $2561\left(0.94^{*}\right)$ & $2246\left(0.88^{\text {ns }}\right)$ \\
$>600$ & $2495\left(0.94^{*}\right)$ & N.D. & N.D. \\
\hline
\end{tabular}

${ }^{\text {a }}$ Temperatures for field-heated soil represent maximum surface temperatures whereas in the oven experiment each sample was exposed to the set temperature level for $30 \mathrm{~min}$.

${ }^{\mathrm{b}}$ N.D.: not analyzed.

${ }^{\mathrm{c}}$ The $r^{2}$ values for the fitted modified Langmuir equation $\left(X=X_{\mathrm{m}}-K^{-1 / 2} X_{\mathrm{m}}^{1 / 2}(X / C)^{1 / 2}\right.$, see text) are given in brackets following the sorption maxima. An asterisk indicates statistical significance at $P<0.05$ while $r^{2}$ values followed by an asterisk are statistically significant at $P<0.05$.

to $\sim 2600 \mathrm{mg} \mathrm{P} \mathrm{kg}^{-1}$ at $450{ }^{\circ} \mathrm{C}$ exposure. Intense field burning increased $X_{\mathrm{m}}$ of the slashed soil from $\sim 2500 \mathrm{mg} \mathrm{P} \mathrm{kg}^{-1}$ at $100{ }^{\circ} \mathrm{C}$ to $\sim 3200 \mathrm{mg} \mathrm{P} \mathrm{kg}^{-1}$ at $600^{\circ} \mathrm{C}$ exposure (Table 2). The increase in sorption capacity in the field-burned samples was larger than the increase in the oven experiment.

Kuo (1988) reported a significant correlation between $X_{\mathrm{m}}$ and the recovery of added $\mathrm{P}$ over a wide range of soils. This is not surprising as $\mathrm{P}$ deficient soils with a large sorption capacity can retain large quantities of P. Similar to the results of this study, Kwari and Batey (1991) observed an apparent enhancement of the effect of fire on maximum sorption capacity in a field burn with ash addition versus static oven heating. They suggested that the additional increase in sorption capacity with ash addition was due to the replacement of hydroxyl ions by the phosphate added in the ash. However, because the present study did not have a true pre-burn control for the field-burned samples other than the soil from the surrounding forest, effects of ash addition on enhancing the sorption capacity may be confounded by spatial differences. Further research is needed to test this hypothesis.

Several factors could play a role in heat-induced changes in sorption with or without the addition of ash. These factors include changes in: (1) soil solution $\mathrm{pH}$; (2) mineralogical composition and specific surface area; (3) the presence of chemical species such as DOC that compete with P for sorption sites; and (4) the capacity of soil minerals to retain P. Each of these factors were studied using a combination of field- and oven-heated samples.

\subsection{Soil $p H$}

Oven heating increased the $\mathrm{pH}$ of the forest soil from 4.5 to 4.9 after exposure to $600{ }^{\circ} \mathrm{C}$ (Fig. 1). Phosphorus addition also increased the $\mathrm{pH}$ of the soil solution. This increase was larger when the soil had already been exposed to heat. For example, the addition of $20 \mathrm{ml}$ of a $289 \mathrm{mg} \mathrm{Pl}^{-1} 0.01 \mathrm{M} \mathrm{NaCl}$ solution resulted in an increase in $\mathrm{pH}$ from 4.5 to 6.4 for the unburned topsoil. An increase from 4.9 in un-amended soil to 7.6 upon $\mathrm{P}$ addition occurred with the same sample after heating at 450 and $600^{\circ} \mathrm{C}$. Similar trends were found for the $5-15 \mathrm{~cm}$ layer (results not shown). The increase of $\mathrm{pH}$ due to phosphate addition may be linked to the formation of Al-P complexes (P liming). Conversely, a strictly fire-induced increase in $\mathrm{pH}$ is not likely to enhance $\mathrm{P}$ sorption because such an increase in $\mathrm{pH}$ would result in the loss of positively-charged sorption sites and thereby decrease $X_{\mathrm{m}}$.

\subsection{Mineral soil-specific surface area}

Results reported elsewhere suggest a heat-induced conversion of goethite to maghemite (Ketterings et al., 2000). Pure, synthetic goethite (>4260 $\mathrm{mg} \mathrm{Pg}^{-1}$ ) has a substantially higher $X_{\mathrm{m}}$ than maghemite $\left(\sim 1800 \mathrm{mg} \mathrm{P} \mathrm{kg}^{-1}\right)$. This would imply a decrease 


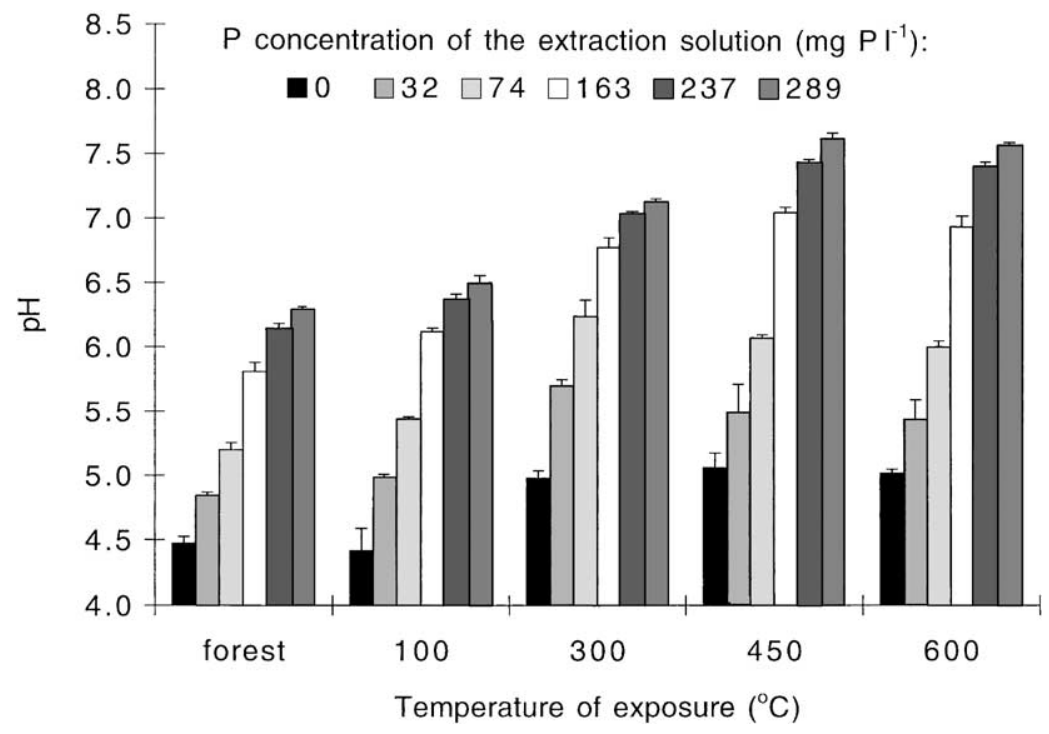

Fig. 1. Effects of $30 \mathrm{~min}$ static heating and $\mathrm{P}$ addition on $\mathrm{pH}$ of air-dried surface soil $(0-5 \mathrm{~cm})$ from Jambi Province, Sumatra, Indonesia. Vertical (error) bars represent one standard deviation. Standard error of difference of any mean comparison $(F<0.001)$ is 0.08 .

in $X_{\mathrm{m}}$ with increasing temperature of exposure and hence contradict the trends observed in the field samples and the oven experiment.

The specific surface area measurements of sand, silt and clay showed that for MST $<600{ }^{\circ} \mathrm{C}$, heat exposure increased the specific surface area of the clay and silt fractions (Table 3 ) resulting in an increase in bulk soil-specific surface area from $39 \mathrm{~m}^{2} \mathrm{~g}^{-1}$ in unburned soil to $57 \mathrm{~m}^{2} \mathrm{~g}^{-1}$ in soil exposed to $600{ }^{\circ} \mathrm{C}$ (Fig. 2). In the combusted surface soil, the loss of kaolinite and gibbsite (Ketterings et al., 2000) and a dramatic shift from a clay to sand texture coincided with the formation of a glassy phase with a specific surface area that exceeded that of the clay faction (Table 3 ) resulting in a bulk soil specific surface area of $75 \mathrm{~m}^{2} \mathrm{~g}^{-1}$. An increase from $36 \mathrm{~m}^{2} \mathrm{~g}^{-1}$ in unburned soil to $55 \mathrm{~m}^{2} \mathrm{~g}^{-1}$ in

Table 3

Effect of heat on soil texture ${ }^{a}$ (modified from Ketterings et al., 2000) and specific surface area (results from this study) in field-burned locations exposed to different intensity fires

\begin{tabular}{|c|c|c|c|c|c|c|}
\hline \multirow{2}{*}{$\begin{array}{l}\text { Temperature of } \\
\text { exposure }\left({ }^{\circ} \mathrm{C}\right)\end{array}$} & \multicolumn{3}{|c|}{$0-5 \mathrm{~cm}$ depth } & \multicolumn{3}{|c|}{$5-15 \mathrm{~cm}$ depth } \\
\hline & Sand & Silt & Clay & Sand & Silt & Clay \\
\hline & \multicolumn{6}{|c|}{ Texture $\left(\mathrm{g} \mathrm{kg}^{-1}\right)$} \\
\hline 100 & 38 & 228 & 735 & 36 & 170 & 794 \\
\hline 300 & 58 & 182 & 761 & 31 & 184 & 786 \\
\hline 600 & 92 & 213 & 696 & 39 & 179 & 783 \\
\hline \multirow[t]{2}{*}{$>600$} & 829 & 63 & 108 & N.D. ${ }^{b}$ & N.D. & N.D. \\
\hline & \multicolumn{6}{|c|}{ Specific surface area $\left(\mathrm{m}^{2} \mathrm{~g}^{-1}\right)$} \\
\hline 100 & 0.1 & 2.9 & 45.3 & 0.1 & 1.2 & 49.7 \\
\hline 300 & 0.1 & 2.9 & 47.6 & 0.1 & 2.1 & 50.3 \\
\hline 600 & 2.4 & 10.4 & 44.7 & 0.1 & 3.8 & 51.0 \\
\hline$>600$ & 59.7 & 4.7 & 10.7 & N.D. & N.D. & N.D. \\
\hline
\end{tabular}

${ }^{\text {a }}$ Sand $=2-0.05 \mathrm{~mm}$, silt $=50-2 \mu \mathrm{m}$, clay $=<2 \mu \mathrm{m}$.

${ }^{\mathrm{b}}$ N.D.: not analyzed. 


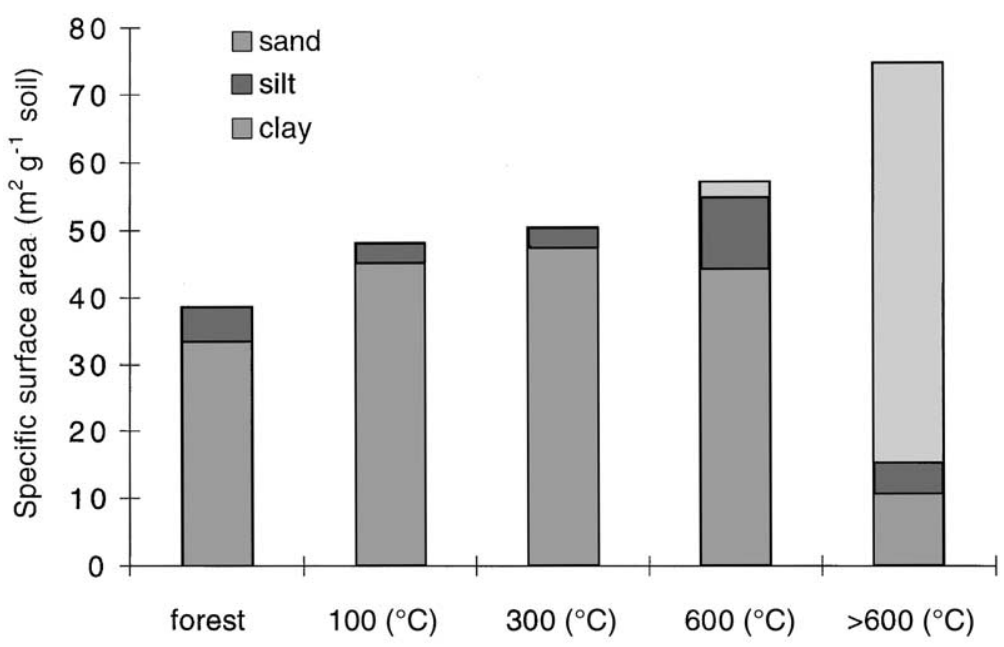

Field burn maximum surface temperatures

Fig. 2. Specific surface area of sand, silt and clay fractions of broadcast field-burned soil samples (Oxisol) from Jambi Province, Sumatra, Indonesia.

soil exposed to $600{ }^{\circ} \mathrm{C}$ was observed for the $5-15 \mathrm{~cm}$ layer. This increase was mostly due to an increase in the specific surface area of the clay fraction (Table 3 ).

The bulk soil $X_{\mathrm{m}}$ of the $0-5 \mathrm{~cm}$ layer was related to specific surface area and particle size distribution according to the following regression equation $(n=5$, $\left.r^{2}=1.00\right)$ :

$$
\begin{aligned}
X_{\mathrm{m}}= & 0.83 \times \mathrm{SS}_{\text {clay }} \times \mathrm{TC}+5.77 \times \mathrm{SS}_{\text {silt }} \times \mathrm{TSI} \\
& +0.60 \times \mathrm{SS}_{\text {sand }} \times \mathrm{TS}-641
\end{aligned}
$$

where $X_{\mathrm{m}}$ is the maximum sorption capacity in $\mathrm{mg} \mathrm{Pkg}{ }^{-1}$ soil; $\mathrm{SS}_{\text {fraction }}$ the specific surface area in $\mathrm{m}^{2} \mathrm{~g}^{-1}$; TC the total clay in percent; TSI the total silt in percent; and TS the total sand in percent. Fire-induced changes in both texture and specific surface area for each textural fraction contributed to the observed alterations of $X_{\mathrm{m}}$.

The overall increase in specific surface area with heating provides additional evidence for the fire-induced formation of amorphous materials. This material is likely to have a higher P sorption capacity since $X_{\mathrm{m}}$ increases in the order: 2:1 minerals < kaolinite $<$ gibbsite $=$ goethite $<$ amorphous oxides (Sanchez, 1976). The observed increase in $X_{\mathrm{m}}$ with heat exposure in these experiments suggests that the loss of sorption sites due to the decomposition of kaolinite, gibbsite and goethite is offset by the formation of an amorphous phase with a higher specific surface area.

\subsection{Total and dissolved soil carbon}

Total organic $\mathrm{C}$ was reduced from 67 to $19 \mathrm{~g} \mathrm{C} \mathrm{kg}^{-1}$ soil by oven-heating the forest surface soil to $600^{\circ} \mathrm{C}$ (data not shown). By comparison, the field combusted surface soil contained only $10 \mathrm{~g} \mathrm{C} \mathrm{kg}^{-1}$ soil. The organic $\mathrm{C}$ content of the $5-15 \mathrm{~cm}$ layer decreased from $20 \mathrm{~g} \mathrm{C} \mathrm{kg}^{-1}$ soil prior to heat exposure to $1 \mathrm{~g} \mathrm{C} \mathrm{kg}^{-1}$ soil after oven-heating at $600^{\circ} \mathrm{C}$.

DOC followed a similar trend. The amount of DOC was reduced from $710 \mathrm{mg} \mathrm{kg}^{-1}$ in unburned forest soil to $7 \mathrm{mg} \mathrm{kg}^{-1}$ following exposure to $600^{\circ} \mathrm{C}$ (Fig. 3). The addition of inorganic $\mathrm{P}$ increased the amount of DOC extracted from the unburned soil, but this effect diminished with increasing temperature. Phosphate addition to soil burned at $600{ }^{\circ} \mathrm{C}$ only slightly increased the DOC content of the extraction solution, most likely due to the severe loss of total C. Dissolved $\mathrm{HCO}_{3}{ }^{-}$and $\mathrm{CO}_{2}$ (dissolved inorganic $\mathrm{C}$, DIC) amounted to $98 \mathrm{mg} \mathrm{kg}^{-1}$ or $8 \%$ of the total amount of dissolved C (DTC) in the unburned soil. In the $600^{\circ} \mathrm{C}$ exposed soil, DIC amounted to $6 \mathrm{mg} \mathrm{kg}^{-1}$ or $47 \%$ of the DTC (results not shown). 


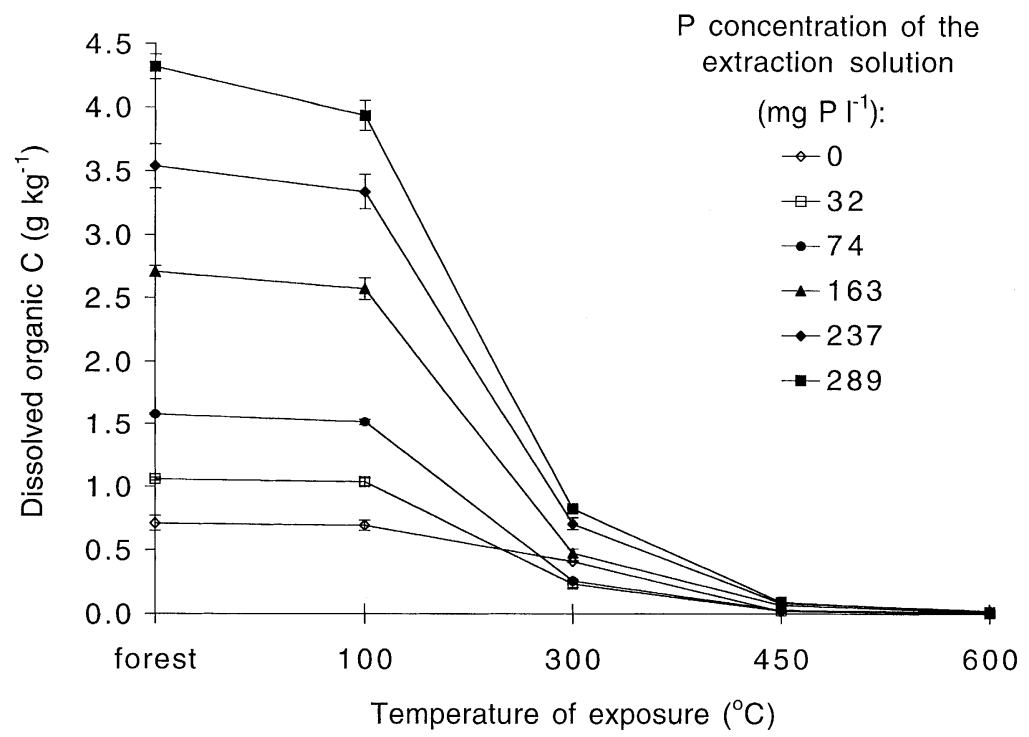

Fig. 3. Effects of $30 \mathrm{~min}$ static heating of air-dried soil and $\mathrm{P}$ addition on dissolved organic carbon of air-dried surface soil $(0-5 \mathrm{~cm})$. Vertical bars represent \pm one standard deviation. Standard error of difference of any mean comparison $(F<0.001)$ is 0.056 .

A decrease in DOC due to heat exposure should lead to an increase in $\mathrm{P}$ sorption as organic acids no longer compete with P for sorption sites (Geelhoed, 1998). Furthermore, the loss of total $C$ from the soil will lead to an increase in $X_{\mathrm{m}}$ due to the removal of organic-mineral complexes. Thus, larger amounts of $\mathrm{P}$ will be needed to obtain similar solution concentrations as observed in the experiment. However, these changes in soil C cannot explain the decrease in $X_{\mathrm{m}}$ for combusted surface soil as compared to the $600^{\circ} \mathrm{C}$ exposed soil. This loss of sorption sites is more likely a result of soil textural and mineralogical changes (see previous discussion).

\subsection{Affinity constants, distribution coefficients and soil $P$ recovery}

The $\mathrm{P}$ affinity constant $(K)$ increased from $2.011 \mathrm{mg}^{-1}$ (unburned forest) to $15.201 \mathrm{mg}^{-1}$ (at $600{ }^{\circ} \mathrm{C}$ exposure) with oven heating of the $0-5 \mathrm{~cm}$ layer from the forest soil (Table 4). These results concur with but are more extreme than those obtained in a field study by Romanya et al. (1994) in which the $K$ of the $0-2.5 \mathrm{~cm}$ surface layer increased from 3.23 to $4.01 \mathrm{l} \mathrm{mg}^{-1}$ after a low-intensity burn of an Australian soil. Contrary to trends for the oven-heated samples,
$K$ s for all field-burned samples (except the combusted surface soil) in this study were less than $1.001 \mathrm{mg}^{-1}$, and an increase in temperature led to a decrease in $K$.

Romanya et al. (1994) also measured a low $K$ value of $0.291 \mathrm{mg}^{-1}$ in an intensively burned and ash-covered surface soil. This value was lower than the $K$ value of both the unburned soil $\left(K=3.231 \mathrm{mg}^{-1}\right)$ and the low burn intensity samples $\left(K=4.01 \mathrm{lmg}^{-1}\right)$, suggesting that ash addition lowered the $\mathrm{P}$ affinity constant. A decrease in $K$ with ash addition implies a weaker binding of adsorbed $\mathrm{P}$, which could be due to locally high $\mathrm{P}$ concentrations and/or the presence of other adsorbing anions added with the ash. Geelhoed (1998), e.g. showed that competitive adsorption of sulfate and citrate on goethite surfaces resulted in an apparent decrease in the affinity for phosphate and a large relative increase in the soluble phosphate concentration. The Geelhoed (1998) study concluded that the extent of this competition increased with a larger surface affinity and concentration of the competing anion. Thus, the addition of $\mathrm{P}$ and other (in)organic anions in the ash may have decreased the $\mathrm{P}$ affinity of the field-burned soil giving rise to higher $\mathrm{P}$ concentrations in the soil solution.

The modified Langmuir sorption isotherms (Eq. (1)) were used to calculate the amount of $\mathrm{P}$ sorbed at 
Table 4

Affinity constants $(K)$ for oven-heated ${ }^{\mathrm{a}}$ surface $(0-5 \mathrm{~cm})$ and sub-surface soil $(5-15 \mathrm{~cm})$ and field-heated surface soil $(0-5 \mathrm{~cm})$

\begin{tabular}{llll}
\hline $\begin{array}{l}\text { Temperature of } \\
\text { exposure }\left({ }^{\circ} \mathrm{C}\right)\end{array}$ & $\begin{array}{l}\text { Field-heated } \\
\text { soil }\left(1 \mathrm{mg}^{-1}\right)\end{array}$ & \multicolumn{2}{c}{ Oven-heated soil $\left(1 \mathrm{mg}^{-1}\right)$} \\
\cline { 3 - 4 } & & $0-5 \mathrm{~cm}$ & $5-15 \mathrm{~cm}$ \\
\hline Unburned forest & N.D. ${ }^{\mathrm{b}}$ & $2.01\left(0.95^{*}\right)^{\mathrm{c}}$ & $1.78\left(0.88^{*}\right)$ \\
100 & $0.63\left(0.97^{*}\right)$ & $2.03\left(0.94^{*}\right)$ & $2.80\left(0.87^{*}\right)$ \\
300 & $0.48\left(0.99^{*}\right)$ & $6.55\left(0.92^{*}\right)$ & $7.83\left(0.89^{*}\right)$ \\
450 & N.D. & $12.62\left(0.96^{\mathrm{ns}}\right)$ & $18.35\left(0.91^{*}\right)$ \\
600 & $0.34\left(0.98^{*}\right)$ & $15.20\left(0.94^{*}\right)$ & $17.44\left(0.88^{\mathrm{ns}}\right)$ \\
$>600$ & $2.28\left(0.94^{*}\right)$ & N.D. & N.D.
\end{tabular}

${ }^{\text {a }}$ Temperatures for field-heated soil represent maximum surface temperatures whereas in the oven experiment each sample was exposed to the set temperature level for $30 \mathrm{~min}$.

b N.D.: not analyzed.

${ }^{c} r^{2}$ values for the fitted modified Langmuir equation $\left(X=X_{\mathrm{m}}-K^{-1 / 2} X_{\mathrm{m}}^{1 / 2}(X / C)^{1 / 2}\right.$, see text) are given in brackets following the affinity constants. An asterisk indicates statistical significance at $P<0.05$ while $r^{2}$ values followed by an asterisk are statistically insignificant at $P<0.05$.

a solution concentration $(C)$ of $0.2 \mathrm{mg} \mathrm{Pl}^{-1}$, which is often considered a benchmark concentration for non-P limited plant growth. In the oven experiment, the amount of $\mathrm{P}$ sorbed at $C=0.2 \mathrm{mg} \mathrm{Pl}^{-1}$ increased with temperature of exposure from $514 \mathrm{mg} \mathrm{P} \mathrm{kg}^{-1}$ in unburned soil to a maximum of $1512 \mathrm{mg} \mathrm{P} \mathrm{kg}^{-1}$ soil at $450{ }^{\circ} \mathrm{C}$ (Table 5). In the field samples, the amount of $\mathrm{P}$ sorbed at $0.2 \mathrm{mg} \mathrm{P}^{-1}$ soil solution concentration decreased with heat exposure from $251 \mathrm{mg} \mathrm{Pkg}^{-1}$ soil in soil exposed to $100^{\circ} \mathrm{C}$ to $196 \mathrm{mg} \mathrm{P} \mathrm{kg}^{-1}$ soil in $600^{\circ} \mathrm{C}$ exposed soil which is consistent with the previously observed decreases in affinity constants. Further combustion of the soil resulted in a sharp increase in amount of $\mathrm{P}$ sorbed (Table 5).

Table 5

Amount of sorbed $\mathrm{P}$ at a soil solution $\mathrm{P}$ content of $0.2 \mathrm{mg} \mathrm{Pl}^{-1}$ for oven-heated ${ }^{\mathrm{a}}$ surface $(0-5 \mathrm{~cm})$ and sub-surface soil $(5-15 \mathrm{~cm})$ and field-heated surface soil $(0-5 \mathrm{~cm})$

\begin{tabular}{llll}
\hline $\begin{array}{l}\text { Temperature of } \\
\text { exposure }\left({ }^{\circ} \mathrm{C}\right)\end{array}$ & $\begin{array}{l}\text { Field-heated soil } \\
\left(\mathrm{mg}^{-1} \mathrm{~kg}^{-1}\right)\end{array}$ & $\begin{array}{l}\text { Oven-heated soil } \\
\left(\mathrm{mg}^{-1} \mathrm{~kg}^{-1}\right)\end{array}$ \\
\cline { 3 - 4 } & & $0-5 \mathrm{~cm}$ & $5-15 \mathrm{~cm}$ \\
\hline Unburned forest & N.D. $^{\mathrm{b}}$ & 514 & 414 \\
100 & 251 & 525 & 515 \\
300 & 218 & 1158 & 1037 \\
450 & N.D. & 1512 & 1567 \\
600 & 196 & 1454 & 1323 \\
$>600$ & 634 & N.D. & N.D. \\
\hline
\end{tabular}

${ }^{a}$ Temperatures for field-heated soil represent maximum surface temperatures whereas in the oven experiment each sample was exposed to the set temperature level for $30 \mathrm{~min}$.

${ }^{\mathrm{b}}$ N.D.: not analyzed.
Distribution coefficients $\left(K_{\mathrm{d}} \mathrm{s}\right.$, calculated as $X / C$ after conversion to common units) were used to assess $\mathrm{P}$ availability as a function of the solution $\mathrm{P}$ concentration. Exposing soil to oven temperatures of $\leq 450{ }^{\circ} \mathrm{C}$ increased the $K_{\mathrm{d}}$ with increasing temperature of exposure. Upon further heating a slight decrease was observed (Fig. 4). These results suggest that fire does not just shift the soil $\mathrm{P}$ equilibrium along a fixed curve but affects the nature of the equilibrium. The effects of heat exposure and ash addition on affinity constants and sorption maxima (as estimated with the modified Langmuir equation) and the increase in surface area of the soil minerals give further support to this hypothesis.

\subsection{Comparing $P$ inputs with changes in $P$ sorption}

Sequential increases in $X_{\mathrm{m}}$ of 216 and $742 \mathrm{mg} \mathrm{P} \mathrm{kg}^{-1}$ can be calculated by comparing the $X_{\mathrm{m}}$ of the field soil after burning at 100,300 and $600{ }^{\circ} \mathrm{C}$ (Table 2). Assuming a fire-affected depth of $5 \mathrm{~cm}$ and a bulk density of $0.80 \mathrm{~kg} \mathrm{dm}^{-3}$, these quantities would imply increases in P sorption of 86 and $297 \mathrm{~kg} \mathrm{Pha}^{-1}$ for the 300 and $600^{\circ} \mathrm{C}$ fires, respectively. The above ground biomass of five secondary forests in Sumatra, ranging in age from 15 to $>60$ years, was found to range from 49 to $225 \mathrm{mg}$ dry weight ha ${ }^{-1}$ (unpublished results). On average, P comprised $0.03 \%$ of the biomass, resulting in estimated above ground $\mathrm{P}$ pools varying from 11 to $51 \mathrm{~kg} \mathrm{Pha}^{-1}$. Assuming a commonly reported range of burn efficiencies for slashed 


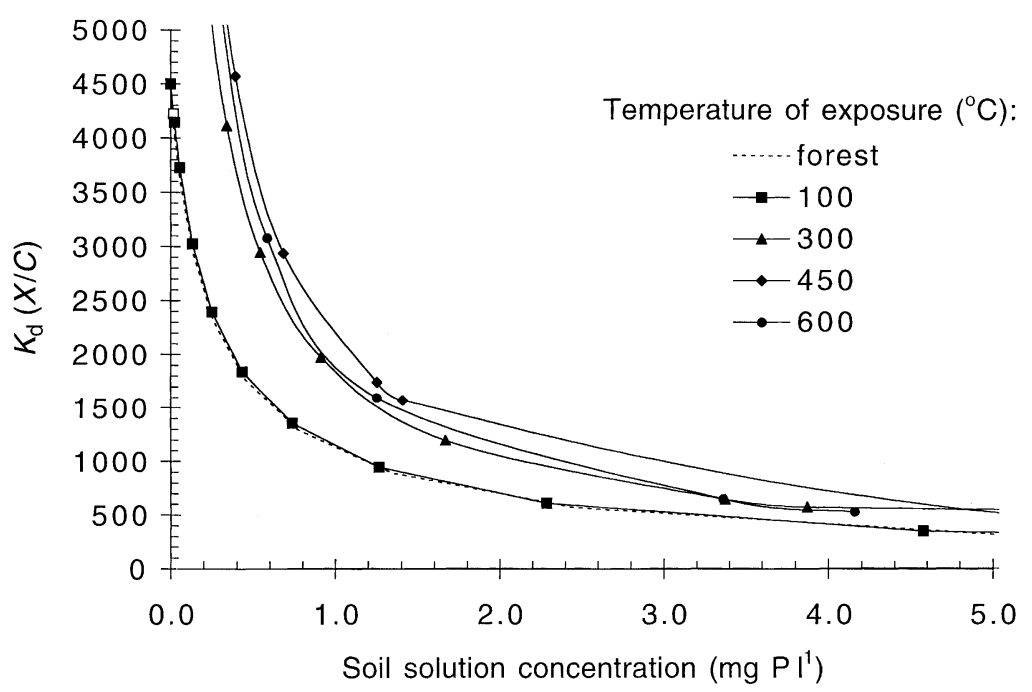

Fig. 4. Phosphorus distribution coefficients $\left(K_{\mathrm{d}}\right.$ estimated as amount of $\mathrm{P}$ sorbed to the soil particles divided by the amount of $\mathrm{P}$ in solution) as a function of solution $\mathrm{P}$ concentration for an Oxisol $(0-5 \mathrm{~cm})$ from Jambi Province, Sumatra, Indonesia, exposed for 30 min to different oven temperatures.

forest fires of $40-70 \%$, the amount of P released from the trees of these forests to the soil would range from 5 to $36 \mathrm{~kg} \mathrm{Pha}^{-1}$. When undergrowth and litter were added to the biomass estimate, the total amount of released $\mathrm{P}$ ranged from 15 to $43 \mathrm{~kg} \mathrm{Pha}^{-1}$ (unpublished results). The potential amount of $\mathrm{P}$ released by slash-and-burn of the forests is, thus, far less than the amount that must be added to the soil to saturate the exchange complex following medium to high intensity fires. The generally observed increase in available $\mathrm{P}$ following slash-and-burn is then possible only if the ash is concentrated on very small areas (locally over-saturated creating high solution concentrations) and/or the extra sorbed $\mathrm{P}$ has a $K_{\mathrm{d}}$ equal to or lower than the pre-burn constant.

\subsection{Implications land-use management}

The slashed and burned field in this study was planted with rubber $(H$. brasiliensis) seedlings intercropped with cassava (Manihoc esculenta) and various vegetables and fruit trees. Although not done at this specific location, upland rice (Oryza sativa) is frequently planted in the ashes as well. Rubber, and fruit tree seedlings were planted in $20-25 \mathrm{~cm}$ deep planting holes that contained some of the wood-ash as well as cassava. Through this practice, farmers make use of the nutrients in the ash while (as a result of deeper planting) avoiding the negative effects of heat exposure. Thus, heat-induced yield reductions are not expected for these crops. However, high intensity fires may severely impact the establishment of annual crops following the first growing season and similar effects are expected for the establishment of perennial crops, timber, fruit and rubber trees from seeds.

\section{Conclusions}

This study showed that intense fires affect $\mathrm{P}$ availability due to both ash addition and direct heat exposure. At low intensity fires, ash addition dominates $P$ availability because temperatures are generally too low to affect the mineralogical composition of the soils. At medium to high intensity fires (in this study identified as fires with maximum surface temperatures $>300^{\circ} \mathrm{C}$ ) $\mathrm{P}$ fixation increased due to a heat-induced increase in soil mineral surface area and affinity for sorbed P. This could lead to a long-term increase in P fixation and reduced recovery of added $\mathrm{P}$ which may severely shorten annual cropping periods and lead to a gradual decline in soil fertility with repeated burns. 
As stated in the introduction, pre-burn wood removal can be a partial solution to the smoke problems currently associated with high intensity burns. The results of this study suggest that in managing the intensity of slash-and-burn fires, the farmer has to balance between short-term gains in $\mathrm{P}$ availability and long-term costs in increased P sorption. Further studies are needed to quantify the effects of heat-induced increase in $\mathrm{P}$ fixation on the yields of annual crops (i.e. rice) while long-term studies are needed to assess the sustainability of tree-based cropping systems under different fire intensities.

\section{Acknowledgements}

Research expenses in Indonesia were covered by funding from the Alternatives-to-Slash-and-Burn project supported by the Global Environment Facility with United Nations Development Program sponsorship through the International Center for Research in Agroforestry Southeast Asia Regional Program. Q.M.K. was supported by a multiple year European Fellowship. Travel expenses were covered by grants and awards from the International Scholarships Ohio Intern Program, the Office of International Studies, and the Graduate School of the Ohio State University. Salary and research support for J.M.B. were provided by state and federal funds appropriated to the Ohio Agricultural Research and Development Center, The Ohio State University. Special thanks to Dedra Woner for her help with phosphorus analyses, Sandy Jones for particle size determinations, and Ubi Soto for the mineralogical analyses.

\section{References}

American Society for Testing and Materials (ASTM), 1990. Annual Book of ASTM Standards 4.08. Philadelphia, PA.

Andriesse, J.P., Koopmans, T.Th., 1984. A monitoring study on nutrient cycles in soil used for shifting cultivation under various climatic conditions in tropical Asia. Part I. The influence of simulated burning on form and availability of plant nutrients. Agric. Ecosyst. Environ. 2, 1-16.

Geelhoed, J., 1998. Phosphate availability in the soil-root system: integration of oxide surface chemistry, transport and uptake. Doctoral thesis, Agricultural University Wageningen.

Genstat, 1993. Genstat 5 Reference Manual. Clarendon Press, Oxford.
Juo, A.S.R., Manu, A., 1996. Chemical dynamics in slash-and-burn agriculture. Agric. Ecosyst. Environ. 58, 49-60.

Ketterings, Q.M., Bigham, J.M., Laperche, V., 2000. Changes in soil mineralogy and texture caused by slash-and-burn fires in Sumatra, Indonesia. Soil Sci. Soc., Am. J. 64, 1108-1117.

Ketterings, Q.M., Tri Wibowo, T., van Noordwijk, M., Penot, E., 1999. Farmers' perceptions on slash-and-burn as land clearing method for small-scale rubber producers in Sepunggur, Jambi Province, Sumatra, Indonesia. For. Ecol. Manage. 120, 157169.

Kilmer, V.J., Alexander, L.T., 1949. Methods of making mechanical analysis of soils. Soil Sci. 68, 15-24.

Kuo, S., 1988. Application of a modified Langmuir isotherm to phosphate sorption by some acid soils. Soil Sci. Soc., Am. J. 52, 97-102.

Kwari, J.D., Batey, T., 1991. Effect of heating on phosphate sorption and availability in some northeast Nigerian soils. J. Soil Sci. 42, 381-388.

Mehra, O.P., Jackson, M.L., 1960. Iron oxide removal from soils and clays by a dithionite-citrate system buffered with sodium bicarbonate. In: Swineford, A. (Ed.), Proceedings of the 7th National Clay Conference 1958. Washington, DC. Pergamon Press, New York, pp. 317-327.

Nye, P.H., Greenland, D.J., 1960. The soil under shifting cultivation. Technical Communication No. 51. Commonwealth Bureau of Soils, Harpenden.

Romanya, J., Khanna, P.K., Raison, R.J., 1994. Effects of slash burning on soil phosphorus fractions and sorption and desorption of phosphorus. For. Ecol. Manage. 65, 89-103.

Sanchez, P.A., 1976. Properties and Management of Soils in the Tropics. Wiley/Interscience, London.

Schwertmann, U., Cornell, R.M., 1991. Iron Oxides in the Laboratory. VCH Publications, New York.

Serrasolsas, I., Khanna, P.K., 1995. Changes in heated and autoclaved forest soils of southeast Australia. Part II. Phosphorus and phosphatase activity. Biogeochemistry 29, 2541.

Sertsu, S.M., Sanchez, P.A., 1978. Effects of heating on some changes in soil properties in relation to an Ethiopian land management practice. Soil Sci. Soc., Am. J. 42, 940-944.

Simons, L.M., 1998. Indonesia's plaque of fire. National Geographic 149, 100-119.

Slaats, J.J.P., Janssen, B.H., Wessel, M., 1998. Crop production in relation to cultural practices in the Chromolaena ordorata fallow system in Southwest Côte d'Ivoire. Netherlands J. Agric. Sci. 46, 305-317.

Soil Survey Staff, 1999. Soil taxonomy, a basic system of soil classification for making and interpreting soil surveys. 2nd Edition. Agriculture Handbook 436. USDA-NRCS. US Government Printing Office, Washington, DC.

Sreenivasan, A., Aurangabadkar, R.K., 1940. Effect of fire heating on the properties of black cotton soil in comparison with those of gray and of humus treated soils. Soil Sci. 51, 449-462.

Syers, J.K., Brownam, M.G., Smillie, G.W., Corey, R.B., 1973. Phosphate sorption by soils evaluated by the Langmuir adsorption equation. Soil Sci. Soc., Am. Proc. 37, 358-363. 
Tiessen, H., Chacon, P., Cuevas, E., 1994. Phosphorus and nitrogen status in soils and vegetation along a toposequence of dystrophic rainforest on the upper Rio Negro. Oecologia 99, 145-150.

Ulery, A.L., Graham, R.C., 1993. Forest fire effects on soil color and texture. Soil Sci. Soc., Am. J. 57, 135-140.

van Noordwijk, M., Tomich, T.P., Winahyu, R., Murdiyarso, D., Suyanto, Partoharjono, S., Fagi, A.M., 1995. Alternatives to Slash-and-Burn in Indonesia: Summary Report of Phase I. ASB-Indonesia Report No. 4, Bogor.

van Noordwijk, M., Murdiyarso, D., Hairiah, K., Wasrin, U.R., Rachman, A., Tomich, T.P., 1998. Forest soils under alternatives to slash-and-burn agriculture in Sumatra, Indonesia. In: Schulte, A., Ruhiyat, D. (Eds.), Soils of Tropical Forest Ecosystems:
Characteristics, Ecology and Management. Springer, Berlin, pp. $175-185$.

van Rees, K.J.C., Comerford, N.B., Rao, P.S.C., 1990. Defining soil buffer power: implications for ion diffusion and nutrient uptake modeling. Soil Sci. Soc., Am. J. 54, 1505-1507.

van Reuler, H., 1996. Nutrient management over extended cropping periods in the shifting cultivation system of southwest Côte d'Ivoire. Doctoral thesis, Wageningen Agricultural University.

Walkley, A., 1947. A critical examination of a rapid method for determining organic carbon on soils: effects of variations in digestion conditions and of inorganic soil constituents. Soil Sci. 63, 251-263. 